http://dx.doi.org/10.4314/jae.v18i1.14

\title{
Level of Utilization of Traditional and Orthodox Medicines by Rural Dwellers in Ile- Ogbo Community of Osun State, Nigeria
}

\section{Ladele, A.A.* and Bisi-Amosun, 0.0.}

Department of Agricultural Extension and Rural Development

University of Ibadan, Ibadan, Nigeria

*Email: aaladele@yahoo.com

\section{Abstract}

This study examined the level of utilization of traditional and orthodox medicine by rural dwellers in Ile-Ogbo community of Osun State. Structured questionnaires and interview schedules were used to collect data from one hundred and forty adult males and females who were randomly selected from the rural house list generated by snowball technique. Key primary data collected include the level of utilization of traditional, the level of utilization of orthodox medicine and the factors influencing the use of medicines. Data were analyzed using Chi-square, PPMC, $t$-test and regression analysis at $p=0.05$. Results indicate that $81.5 \%$ were between the ages of $20-59$ years, $30.7 \%$ had no formal education and $41.4 \%$ had farming as their main occupation. Majority (82.9\%) rated efficacy and safety as the most important factor influencing the use of orthodox medicine and $50.7 \%$ had preference for orthodox medicine. Household size $(r=0.244)$ had low inverse but significant correlation with the utilization of orthodox medicine. With traditional medicine, there was a significant relationship $(r=0.279)$ between household size and utilization. There existed a significant difference in the utilization of traditional medicine and orthodox medicine (t=-2.734), with orthodox medicine having higher use. It is paramount therefore for relevant agencies to ensure adequate supply of orthodox medical drugs in the rural health centers in order to meet the health needs of rural dwellers.

Key words: Traditional medicine, Orthodox medicine, Utilization

\section{Introduction}

The overall wellbeing of rural dwellers is very essential in achieving sustainable rural development. Health is the most precious of all things and it is the foundation to all happiness. Health affects the productivity of farmers which influences their overall livelihood. The fact that three out of the eight Millennium Development Goals (MDGs) developed by the United Nations touch on health indicates that the importance of good health cannot be overemphasized.

Many societies have developed various traditional methods of managing their health problems using available local resources. Since creation, traditional medicine has 
always existed and it has been a critical part of man's healthcare system. Though traditional medicine does not have scientific validation, its usage over the years proves that it is of high value. It is also relatively cheap and accessible as most of the materials used are locally available.

As social changes occur and societies evolve, orthodox medicine was introduced. Orthodox medicine is a product of sustained research as it has been proven scientifically and subjected to clinical trials. It has brought about successful treatment of diseases that have once been considered untreatable. Science has brought many victories to orthodox health care, successfully dealing with maladies once considered untreatable. Heart attack victims, premature babies, victims of traumatic accidents, and some victims of infectious diseases - all are beneficiaries of orthodox medicine. (Bradstreet, 1998)

In recent times, however, both traditional and orthodox medicines are used by people to respond to their health needs and both are used with the primary objective of curing, managing and preventing diseases and maintaining good health. Traditional medicine has strong historical and cultural roots but its efficacy has not been proven scientifically. Many, but not all, traditional medicines have an inadequate evidence base when measured by these standards as tests for quality and standards for production tend to be less rigorous and controlled. Also, products may escape the strict regulations set up to ensure drug safety and practitioners may not be certified or licensed (Chan, 2008). There is also a general belief (especially in urban areas) that traditional medicine is crude and its contents are diabolical. Requirements and methods for research and evaluation of traditional medicine are complex. For example, it can be difficult to assess the quality of finished herbal products. The safety, effectiveness and quality of finished herbal medicine products depend on the quality of their source materials (which can include hundreds of natural constituents), and how elements are handled through production processes (World Health Organization, 2008).

There is also a general assumption that orthodox medicine is more reliable than other forms of healthcare because it has scientific back-up, but the fact that orthodox medicine is always evolving, can lead to the public being adversely affected as a result of different experimental techniques. The development of antibiotics illustrates the twoedged swords of orthodox medicine; antibiotics created the false hope that modern medical science could eradicate bacterial diseases. Although antibiotics do effectively kill many disease-causing organisms, they also kill the body's beneficial bacteria, which naturally keep harmful bacteria in check. In the long run, antibiotics actually reduce the body's resistance to harmful bacteria (Bradstreet, 1998). Orthodox drugs are also becoming very expensive and unavailable to average income earners and many diseases are developing resistance to orthodox drugs. An example is the increasing resistance of malaria parasites to the cheapest and most common malaria drug in Nigeria-chloroquine (Umunakwe, 2010).

All these factors have led to the rise of global interest in traditional medicine in the last few decades after its neglect with the advent of orthodox medicine. In some Asian and African countries, $80 \%$ of the population depend on traditional medicine for primary health care $(\mathrm{WHO}, 2008)$ and about $60 \%$ of young children in some African countries 
suffering from high fever, presumably caused by malaria, are treated at home with herbal remedies (Chan, 2008).

In Nigeria, 51\% of the population live in rural areas (World Bank, 2011) where the major source of livelihood is agriculture and rural areas serve as the major sources of food for the entire populace as over 70 percent of the active labor force in Nigeria depend on agriculture as a source of livelihood (Food and Agriculture Organization, 2008). Human resources play a dominant role in agriculture because it is labour intensive and health is an important component of human capital. A healthy individual can carry out his/her duties effectively thereby increasing productivity and giving that individual the opportunity to enjoy the outputs of his/her labour fully. Bearing in mind that agriculture in Nigeria is largely unmechanized, lots of physical strength attainable only in good health is required to make good success in farming ventures.

However, most rural dwellers do not have access to quality healthcare due to unavailability of health centers, difficulty in recruiting and retaining medical personnel and poor access to drugs. This has made the achievement of the national health policy goal which is to bring about a comprehensive healthcare system, based on primary healthcare that is promotive, preventive, protective, restorative and rehabilitative to every citizen of the country within the available resources so that individuals and communities are assured of productivity, social wellbeing and enjoyment of life farfetched. It is also further evident in the life expectancy in Nigeria being extremely as low as 52 years against 75 years in Malaysia and 83 years in Japan (World Bank, 2011).

For national development to take place, rural development is very essential and one of the major indicators of this is quality health care delivery.Also, the health status of rural dwellers determines their productivity making it a very crucial factor in the optimal utilization of human resources for agricultural development. Hence, this study will help change agents in designing sustainable intervention programmes because while the health of the rural folks may not be the primary concern of agricultural extension, the bottleneck prevalent ill-health in the rural community portends limited effectiveness of extension work. It is against this background, that this study was carried out to assess the level of utilization of traditional and orthodox medicine by rural dwellers in lle-Ogbo community of Osun State, Nigeria. This is to provide empirical basis for the direction of health care support to the rural dwellers.

\section{Objectives of the study}

The specific objectives of the study were to:

1. determine the personal characteristics of rural dwellers in the study area,

2. assess the rural dwellers' level of use of traditional and orthodox medicine,

3. examine the factors influencing the preference for traditional or orthodox medicine in the study area. 


\section{Statement of hypotheses}

1. There is no significant relationship between the level of utilization of traditional and orthodox medicine and the socio-economic characteristics of the respondents in the study area.

2. There is no significant difference between the level of utilization of traditional medicine and that of orthodox medicine by the rural dwellers.

\section{Methodology}

\section{The study area}

The study area is lle Ogbo community which is the administrative headquarters of Aiyedire Local Government area of Osun State. It is situated midway between Ibadan and Osogbo, the capitals of Oyo and Osun States. Ile-Ogbo community has one state and three local government health centres. The local government health centres are quite small and usually run by auxiliary nurses on rotational shifts. Herbal medicine is the most common type of traditional medicine in the study area and most of the rural dwellers in Ile-Ogbo community have indigenous knowledge on the treatment of common diseases. Most of the herbalists are traditional worshippers and consult the oracle for diagnosis.

The target population comprises all adult males and females in lle-Ogbo community of Osun State, Nigeria. A rural house list generated through snowball technique indicated that there were 2,811 households in the community and $5 \%$ of these were selected for the study amounting to 140 households. 1 out of every 20 households was randomly selected from which an adult male or female was selected.

\section{Method of data collection}

Primary data for the study were collected from respondents using structured questionnaire and interview technique. The questionnaire had 5 sections and contained both open and close ended questions. The questionnaires were self- administered and the questions were translated and interpreted in the respondents' local dialect (Yoruba) for some of the respondents who were illiterates.

The level of utilization of traditional and orthodox medicine which is the dependent variable was measured by asking the respondents to indicate their level of use of traditional and orthodox medicine for each of the diseases and symptoms listed in the questionnaire. They were asked to indicate whether they use traditional and orthodox medicine regularly, occasionally or never which were scored 2,1 and 0 respectively. A total of nineteen (19) diseases/symptoms were listed, which implies that the maximum score was 38 while the minimum was 0 . The mean scores for each type of medicine were used to group the respondents into high and low categories. To determine the factors influencing the level of utilization of traditional and orthodox medicine, each of the respondents was asked to indicate the importance of listed factors such as cost, efficacy and safety, accessibility, time delay, authenticity, diabolical content, diagnosis and cultural belief on a 3-point scale of very important (2), important (1) and not important (0).

\section{Validation of research instrument}


ISSN 1119-944X

The contents of the questionnaire and interview schedule were subjected to comparison with contents of relevant instruments from literature and also face validity by experts in the Department of Agricultural Extension and Rural Development, University of Ibadan.

\section{Techniques of data analysis}

The data collected were analyzed using descriptive statistics such as frequency distribution tables, percentages and mean. Hypothesis one was analyzed using chisquare and Pearson Product Moment Correlation (PPMC) while hypothesis two was analyzed using T-test. 


\section{Results and discussion}

\section{Socio-economic Characteristics of Respondents}

Table 1 shows that majority (61.5\%) of the rural dwellers were between 30 and 59 years old. The average age of the respondents was about 44 years, indicating that the majority belong to the active workforce population (Akinbile, 2007). However, the population of youths who according to the United Nations are those within the age group $15-24$ is low as only $20 \%$ of the respondents were within this age range which implies increasing absence of young people in rural communities because of farm drudgery, absence of social infrastructure (such as health centres), poor farm incomes and the general low life expectancy in rural areas (Echebiri and Mbanasor, 2003). Slightly more than half $(51.4 \%)$ of the respondents were females. This indicates that the utilization of medicine is not gender sensitive as health is the foundation of all other aspects of life and the ultimate aim of any medical service is to reduce mortality and morbidity of people regardless of their sex (Shehu and Mallam, 2007). Majority (84.3\%) of them were married and they need to provide for the needs of their household which includes health care. According to Akinbile (2007), marriage confers responsibility therefore health case within the family setting is expected to be better as it provides opportunity for members to be their brothers' keepers because non-married individuals may not be sufficiently sensitive to their health needs.

The table further reveals that $55 \%$ of the respondents were Muslims, $40 \%$ Christians and $5 \%$ traditionalists. This implies that majority of the respondents $(95 \%)$ practice contemporary religion and this may hinder the use of traditional medicine due to the belief that some of its aspects are diabolical in terms of sorcery and incantation. However, some religious sect may reject utilization of both types of medicine based on the belief that healing is spiritual not physical. A greater proportion $(69.3 \%)$ of the rural dwellers had formal education which may affect people's choice of medicine and their attitude towards it as education influences a change in attitude, skills or knowledge therefore the belief of the Western world that traditional medicine is primitive and unscientific may transcend to people with western or formal education. Majority $(41.1 \%)$ engaged in farming as their main income generating activity, since agriculture in Nigeria is largely unmechanized, lots of physical strength attainable only in good health is required to make good success in farming ventures. Majority of the respondents $(50 \%)$ had a household size of 6-10 while the average household size was 9 indicating a fairly large size which implies that an average family head has a lot of dependants. The implication of this is that rural dwellers may opt for cheaper means of meeting their health needs and that of their family members because according to Shehu et al (2007), the bulk of people living in rural areas have low economic status and the cost of modern medicine is usually beyond their means. Consequently, people often have to depend upon traditional medical care which is within their locality and economic reach. 
Table 1: Distribution of Respondents according to socio-economic characteristics

\begin{tabular}{|c|c|c|}
\hline Variables & Percentage $(n=140)$ & Mean \\
\hline \multicolumn{3}{|l|}{ Sex } \\
\hline Male & 48.6 & \\
\hline Female & 51.4 & \\
\hline Sub-total (a) & 100 & \\
\hline \multicolumn{3}{|l|}{ Age } \\
\hline $20-29$ & 20 & 43.5 \\
\hline $30-39$ & 23.6 & \\
\hline $40-49$ & 24.3 & \\
\hline $50-59$ & 13.6 & \\
\hline $60-69$ & 15 & \\
\hline 70 and above & 3.5 & \\
\hline Sub-total (b) & 100 & \\
\hline \multicolumn{3}{|l|}{ Marital Status } \\
\hline Single & 9.3 & \\
\hline Married & 84.3 & \\
\hline Divorced & 2.1 & \\
\hline Widowed & 4.3 & \\
\hline Sub-total (c) & 100 & \\
\hline \multicolumn{3}{|l|}{ Religion } \\
\hline Christianity & 40 & \\
\hline Islam & 55 & \\
\hline Traditional & 5 & \\
\hline Sub-total (d) & 100 & \\
\hline \multicolumn{3}{|l|}{ Educational Attainment } \\
\hline No formal education & 30.7 & \\
\hline Primary & 25 & \\
\hline Secondary & 28.6 & \\
\hline Tertiary & 12.8 & \\
\hline Adult literacy & 2.9 & \\
\hline Sub-total (e) & 100 & \\
\hline \multicolumn{3}{|l|}{ Major Occupation } \\
\hline Farming & 41.4 & \\
\hline Trading & 18.6 & \\
\hline Artisan & 22.1 & \\
\hline Okada riding & 4.3 & \\
\hline Native doctor & 2.9 & \\
\hline Civil servant & 10.7 & \\
\hline Sub-total (f) & 100 & \\
\hline \multicolumn{3}{|l|}{ Household Size } \\
\hline $1-5$ & 23.6 & \\
\hline $6-10$ & 50 & \\
\hline 11-15 & 18.6 & \\
\hline $16-20$ & 6.4 & \\
\hline $21-25$ & 0.7 & \\
\hline $26-30$ & 0.7 & \\
\hline Sub-total (g) & 100 & \\
\hline
\end{tabular}




\section{Level of utilization of traditional medicine}

Findings in Table 2 shows that $62.9 \%$ of the rural dwellers treat malaria with traditional medicine regularly while $52.9 \%, 42.1 \%$ and $39.3 \%$ of them use traditional medicine regularly to treat pile, diarrhoea and stomach ache respectively. This implies that malaria is the most common disease treated with traditional medicine by the rural dwellers and reflects the findings of WHO (2012), that Nigeria is one of the six highest malaria burdened countries in Africa which account for an estimated $47 \%$ of malaria cases globally and also Chan (2008) which states that $60 \%$ of young children in some African countries suffering from high fever, presumably caused by malaria, are treated at home with herbal remedies which are the most common type of traditional medicine. The high incidence of malaria in the community may also be indicative of the fact that majority of the respondent are farmers because irrigation and the proximity of villages to fields and water sources are some characteristics of agricultural production systems that can create conditions that favor parasitic vectors and facilitate the disease's transmission.

Table 2 also shows that the mean score of the respondents' level of utilization of traditional medicine was 7.51 and $50.7 \%$ had scores above the mean which implies that there is a relatively high use of traditional medicine among the rural dwellers. Chan (2008) stated that for many millions of people, often living in rural areas of developing countries, herbal medicines, traditional treatments, and traditional practitioners are the main and sometimes the only source of health care.

Table 2: Respondents' level of utilization of traditional medicine

\begin{tabular}{|c|c|c|c|c|c|c|}
\hline \multirow[b]{2}{*}{ Diseases/Symptoms } & \multicolumn{2}{|c|}{ Regularly } & \multicolumn{2}{|c|}{ Occasionally } & \multicolumn{2}{|c|}{ Never } \\
\hline & $\mathbf{f}$ & $\%$ & f & $\%$ & f & $\%$ \\
\hline Malaria & 88 & 62.9 & 25 & 17.9 & 27 & 19.2 \\
\hline Cough & 17 & 12.1 & 19 & 13.6 & 104 & 74.3 \\
\hline Diarrhoea & 59 & 42.1 & 6 & 4.3 & 75 & 53.6 \\
\hline Back/Body ache & 34 & 24.3 & 11 & 7.9 & 95 & 67.8 \\
\hline Measles & 10 & 7.1 & 1 & 0.7 & 129 & 92.2 \\
\hline Chest pain & 5 & 3.6 & 3 & 2.1 & 132 & 94.3 \\
\hline Typhoid & 16 & 11.4 & 7 & 5 & 117 & 83.6 \\
\hline Pile & 74 & 52.9 & 12 & 8.6 & 54 & 38.5 \\
\hline Cold & 7 & 5 & 4 & 2.9 & 129 & 92.2 \\
\hline Skin infection & 6 & 4.2 & 5 & 3.6 & 129 & 92.2 \\
\hline Cut \& bruises & 15 & 10.7 & 6 & 4.3 & 119 & 85 \\
\hline Insect bites & 33 & 23.6 & 14 & 10 & 93 & 66.4 \\
\hline Stomach ache & 55 & 39.3 & 15 & 10.7 & 70 & 50 \\
\hline STDs & 31 & 22.1 & 3 & 2.1 & 106 & 75.8 \\
\hline Yellow fever & 2 & 1.4 & 2 & 1.4 & 136 & 97.2 \\
\hline Rheumatism & 6 & 4.3 & 0 & 0 & 139 & 99.3 \\
\hline Mean Distribution & \multicolumn{3}{|c|}{ Percentage } & \multicolumn{3}{|c|}{ Frequency } \\
\hline$<$ Mean & \multicolumn{3}{|c|}{49.3} & \multicolumn{3}{|c|}{69} \\
\hline $\begin{array}{l}\text { Mean and > mean } \\
\text { Mean }=7.5\end{array}$ & \multicolumn{3}{|c|}{50.7} & \multicolumn{3}{|c|}{71} \\
\hline
\end{tabular}




\section{Level of utilization of orthodox medicine}

It can be inferred from Table 3 that $62.9 \%$ of the respondents used orthodox medicine to treat body/back ache and cold while $43.6 \%$ treat malaria and $38.6 \%$ treat cough with orthodox medicine. This implies that majority of the respondents had body/ache, this may be due to the fact that the major occupation in the study area is agriculture which is labour intensive and leads to drudgery. It was observed during the field survey that respondents treated body/back ache and cold with cheap drugs like paracetamol, blood capsules, septrin and procold purchased from drug hawkers, this helps to reduce cost because these drugs are sold to the people in smaller units and also combinations of various drugs can be bought. Although malaria was one of the most common ailments in the area, its treatment with orthodox medicine was reduced as compared to traditional medicine. This may be due to the fact that orthodox medicine is becoming ineffective in the treatment of the disease because malaria parasites are becoming increasingly resistant to chloroquine-the cheapest and most common malarial drug in Nigeria (Umunakwe, 2010).

Table 3 further illustrates that there is a high use of orthodox medicine among the rural dwellers as $54.3 \%$ of the respondents had mean scores above the mean of 9.63 . This is in line with the study carried out by Osemene, Elujoba and Ilori in 2011 which states that that most people believe that orthodox medicine is more efficacious and available than traditional medicine.

Table 3: Respondents' level of utilization of orthodox medicine

\begin{tabular}{|c|c|c|c|c|c|c|}
\hline \multirow[b]{2}{*}{ Diseases/Symptoms } & \multicolumn{2}{|c|}{ Regularly } & \multicolumn{2}{|c|}{ Occasionally } & \multicolumn{2}{|c|}{ Never } \\
\hline & f & $\%$ & f & $\%$ & f & $\%$ \\
\hline Malaria & 61 & 43.6 & 34 & 24.3 & 45 & 32.1 \\
\hline Cough & 54 & 38.6 & 19 & 13.6 & 67 & 47.8 \\
\hline Diarrhoea & 43 & 30.7 & 22 & 15.7 & 75 & 53.6 \\
\hline Back/Body ache & 88 & 62.9 & 15 & 10.7 & 37 & 26.6 \\
\hline Measles & 5 & 3.6 & 2 & 1.4 & 133 & 95 \\
\hline Chest pain & 22 & 15.7 & 9 & 6.4 & 109 & 77.9 \\
\hline Typhoid & 9 & 6.4 & 5 & 3.6 & 126 & 90 \\
\hline Pile & 27 & 19.3 & 11 & 7.9 & 102 & 72.8 \\
\hline Cold & 88 & 62.9 & 18 & 12.9 & 34 & 24.2 \\
\hline Skin infection & 35 & 25 & 14 & 10 & 91 & 65 \\
\hline Cut \& bruises & 41 & 29.3 & 21 & 15 & 58 & 55.7 \\
\hline Insect bites & 7 & 5 & 10 & 7.1 & 123 & 87.9 \\
\hline Stomach ache & 41 & 29.3 & 16 & 11.4 & 83 & 59.3 \\
\hline STDs & 33 & 23.6 & 15 & 0.7 & 92 & 65.7 \\
\hline Yellow fever & 1 & 0.7 & 3 & 2.1 & 136 & 97.2 \\
\hline Rheumatism & 5 & 3.6 & 2 & 1.4 & 133 & 95 \\
\hline Apollo & 2 & 1.4 & 0 & 0 & 0 & 0 \\
\hline Headache & 3 & 2.1 & 0 & 0 & 137 & 97.9 \\
\hline Hypertension & 1 & 0.7 & 0 & 0 & 139 & 99.3 \\
\hline Mean Distribution & \multicolumn{4}{|c|}{ Percentage } & \multicolumn{2}{|c|}{ Frequency } \\
\hline$<$ Mean & \multicolumn{4}{|c|}{45.7} & \multicolumn{2}{|c|}{64} \\
\hline $\begin{array}{l}\text { Mean and > mean } \\
\text { Mean }=9.63\end{array}$ & \multicolumn{4}{|c|}{54.3} & \multicolumn{2}{|c|}{76} \\
\hline
\end{tabular}




\section{Factors influencing the utilization of traditional/orthodox medicine}

Table 4 shows that $82.9 \%, 58.6 \%$ and $45.7 \%$ of the respondents consider efficacy and safety, authenticity and accessibility respectively as very important factors which imply that efficacy and safety was the most important factor respondents consider before using either traditional or orthodox. This may also explain the high level of use of orthodox medicine in the area and corroborates with Yussuph (2008) who submitted that $80 \%$ of rural dwellers in Ona-Ara Local Government Area of Oyo State affirmed that fast recovery is a very important determinant of the use of Primary Health Care Facilities. Time delay at health centres was indicated by $43.6 \%$ of the respondents as an important factor which may influence them to make use of herbal remedies that can be easily prepared in the home or rely on patent medical personnel in the area who move around the community hawking common drugs. This is in line with the work of Ayoola (2008) carried out in the study area that most oil palm processors and nonprocessors in the community either resort to the use of traditional medicine or drug hawkers when they are ill rather than visit health centres. Of the respondents, $65 \%$ believed that diabolical content is not an important factor which suggests that rural dwellers are unlike their urban counterparts who believe that traditional medicine is diabolical.

Table 4 further shows that cost was stated as an important factor by only $35 \%$ of the respondents while $42.9 \%$ considered it to be unimportant. This may be due to the presence of patent medical personnel (drug hawkers) in the community who sell cheap and common drugs. The implication of this is that cost may not necessarily be the most important factor influencing utilization of medicine in the study area and is contrary to widely held view in literature (Chetley, 2007; WHO, 2002) that cost of medical care is the most important factor influencing the utilization of medicine by people.

Table 4: Factors influencing the utilization of traditional/orthodox medicine.

\begin{tabular}{lrrrrrr}
\hline & \multicolumn{3}{c}{$\begin{array}{c}\text { Very } \\
\text { Important }\end{array}$} & \multicolumn{2}{c}{ Important } & \multicolumn{3}{c}{$\begin{array}{c}\text { Not } \\
\text { Important }\end{array}$} \\
& f & \multicolumn{1}{c}{$\%$} & f & $\%$ & $\mathbf{f}$ & $\%$ \\
\hline Cost & 31 & 22.1 & 49 & 35 & 60 & 42.9 \\
Cultural beliefs, customs and traditions & 13 & 9.3 & 45 & 32.1 & 82 & 58.6 \\
Efficacy and safety & 116 & 82.9 & 22 & 15.7 & 2 & 1.4 \\
Accessibility & 64 & 45.7 & 44 & 31.4 & 32 & 22.9 \\
Interaction with health care providers & 9 & 6.5 & 37 & 26.4 & 94 & 67.1 \\
Time Delay & 6 & 4.3 & 61 & 43.6 & 73 & 52.1 \\
Distance from medical centres to places of & 10 & 7.1 & 39 & 27.9 & 91 & 65 \\
residence & & & & & & \\
Authenticity & 82 & 58.6 & 56 & 40 & 2 & 1.4 \\
Diagnosis & 21 & 15 & 41 & 29.3 & 78 & 55.7 \\
Diabolical Content & 17 & 12.1 & 32 & 22.9 & 91 & 65 \\
& & & & & & \\
\hline
\end{tabular}


Relationship between the level of utilization of traditional and orthodox medicine and the socio-economic characteristics of the respondents

There is no significant relationship between the level of utilization of traditional and orthodox medicine and the socio-economic characteristics of the respondents in the study area. Table 5 reveals that for traditional medicine, age and household size of the respondents were significantly correlated to utilization with $r=0.231$ and $p<0.05$ and $r=$ $0.279, p<0.05$ respectively. It can be inferred from this that the use of traditional medicine is common among the aged which may be because they are less amenable towards change as compared to youths and also the deep and ancient cultural roots of traditional medicine may influence its use by older people who are usually entrenched in their social system. The findings also suggest that respondents with large household size tend to use traditional medicine more because it is relatively cheap and affordable. However, for orthodox medicine, the respondents' household size had a significant but negative relationship with the utilization $(r=-0.244, p<0.05)$. This means that people with large household sizes use less of orthodox medicine while there is a high level of use of orthodox medicine by people who have small household size. This may be due to cost of medicine as orthodox medicine is relatively expensive as compared to traditional medicine.

Table 6 shows that a positive and significant relationship was found between the educational attainment and the level of utilization of traditional $\left(x^{2}=22.393, p<0.05\right)$ and orthodox medicine $\left(x^{2}=12.527, p<0.05\right)$. This implies that the more educated people are, the lower their use of traditional medicine while people with low level of education make more use of traditional medicine. Religion was significantly related to the level of utilization of traditional medicine by the respondents $\left(x^{2}=23.133, p<0.05\right)$. This may be because some people's basic beliefs about God, norms and values influence their use of traditional medicine (the belief that traditional medicine is diabolical).

Table 5: PPMC analysis of relationship between selected personal characteristics of the respondents and their level of utilization of traditional and orthodox medicine

\begin{tabular}{lcllcll}
\hline & \multicolumn{3}{c}{ Traditional Medicine } & \multicolumn{3}{c}{ Orthodox Medicine } \\
\hline Variables & $r$ & $p$ value & Decision & $r$ & $p$ value & Decision \\
\hline Age & 0.231 & 0.007 & $\mathrm{~S}$ & -0.137 & 0.113 & $\mathrm{NS}$ \\
Household size & 0.279 & 0.001 & $\mathrm{~S}$ & -0.244 & 0.004 & $\mathrm{~S}$ \\
\hline
\end{tabular}

Table 6: Chi-square analysis of relationship between personal characteristics of respondents and the level of utilization of traditional and orthodox medicine

\begin{tabular}{lllllllll}
\hline & \multicolumn{3}{c}{ Traditional medicine } & \multicolumn{3}{c}{ Orthodox medicine } \\
\hline Variables & $\mathrm{X}^{2}$ & $\mathrm{df}$ & $\mathrm{p}$ value & Decision & $\mathrm{x}^{2}$ & $\mathrm{df}$ & $\mathrm{p}$ value & Decision \\
\hline Sex & 2.804 & 1 & 0.066 & $\mathrm{NS}$ & 0.337 & 1 & 0.562 & $\mathrm{NS}$ \\
Marital status & 3.661 & 3 & 0.301 & $\mathrm{NS}$ & 1.662 & 3 & 0.645 & $\mathrm{NS}$ \\
Educational & & & & & & & & \\
attainment & 22.393 & 4 & 0.000 & $\mathrm{~S}$ & 12.527 & 4 & 0.014 & $\mathrm{~S}$ \\
Religion & 23.13 & 2 & 0.000 & $\mathrm{~S}$ & 5.506 & 2 & 0.064 & $\mathrm{NS}$ \\
& 3 & & & & & & & \\
\hline
\end{tabular}


Difference in the level of utilization of traditional medicine and the level of utilization of orthodox medicine

There is no significant difference between the level of utilization of traditional medicine and that of orthodox medicine by the rural dwellers. Table 7 shows that $t$ value $=-2.734$ and $p$ value $<0.05$, this implies that there was a significant difference in the utilization of traditional and orthodox medicine in Ile-Ogbo community of Osun State. It can also be deduced from the table that the level of utilization of orthodox medicine is higher than the level of utilization of traditional medicine among the rural dwellers. This implication of this is that the respondents make use of orthodox medicine more than traditional medicine and this is contrary to the widely held view in literature that $80 \%$ of the population in developing countries depend on traditional medicine. This is also in line with the work of Osemene et al (2011) that only $41 \%$ of Nigerians take herbal medicines as their first drug choice.

Table 7: T-test analysis of difference between traditional and orthodox medicine

\begin{tabular}{|c|c|c|c|c|c|c|c|}
\hline Variables & Mean & $\begin{array}{l}\text { Std } \\
\text { Deviatio } \\
n\end{array}$ & $\begin{array}{l}\text { Std. } \\
\text { Error } \\
\text { Mean }\end{array}$ & $\begin{array}{l}\mathrm{t} \\
\text { value }\end{array}$ & $p$ value & df & $\begin{array}{l}\text { Decisio } \\
\mathrm{n}\end{array}$ \\
\hline Traditional & 7.507 & 5.14187 & 0.43457 & \multirow{2}{*}{-2.734} & \multirow{2}{*}{0.006} & \multirow{2}{*}{139} & \multirow{2}{*}{ S } \\
\hline $\begin{array}{l}\text { Orthodox } \\
\text { medicine }\end{array}$ & $\begin{array}{l}9.628 \\
6\end{array}$ & 5.46584 & 0.46195 & & & & \\
\hline
\end{tabular}

\section{Conclusion and recommendations}

The results of this study indicated that the respondents' level of utilization of orthodox medicine is higher than that of traditional medicine. The study also revealed that malaria was the most common disease that affects the rural dwellers and majority of the respondents treated malaria with traditional medicine. This reiterates the fact that orthodox medicine is becoming ineffective in the treatment of the disease. It was further revealed that the respondents considered efficacy, safety, authenticity and accessibility as the most important factors influencing their utilization of traditional/orthodox medicine. This is contrary to the widely held view in literature that cost is the most important factor influencing the utilization of medicine by people. Reliance on drug hawkers (patent medicine personnel) by the rural dwellers in order to cut cost and avoid time delay at the community health centre was also discovered during the study.

1. Traditional medicine should be integrated into the primary health care system. Research, quality control, assessment of safety, and regulation of traditional medicine should be carried out in order to improve its standard and efficacy.

2. Relevant agencies at the state and local levels should ensure that competent and adequate medical personnel are recruited and retained in the community health centres as this will help to reduce self-medication by the rural dwellers.

3. Educational programmes on drug use and family planning should be provided so that rural dwellers can be sensitized on the potential evils of self-medication and to reduce the number of children rural women bear. This will help in decreasing 
mortality rates in rural areas as an average family head will be able to cater adequately for the health needs of the few dependants.

4. Government should ensure that supply of drugs are sufficient in the health centres so as to reduce the overdependence on drug hawkers which may lead to irrational use of medicine, drug abuse and even death as a result of unadulterated drugs.

\section{References}

Akinbile, L.A. (2007). Social Impact of Limestone Exploitation in Yewa North Local Government Area of Ogun State, Nigeria. Pakistan Journal of Social Science 1: pp107-111.

Ayoola O.C. (2008). "Health Problems of Oil Palm Processors and Non Processors in Ile Ogbo Community, Aiyedire Local Government of Osun State." Unpublished B.Agric Thesis in the Department of Agricultural Extension and Rural Development, University of Ibadan, Nigeria, pp53.

Bradstreet, K. (1998). "Natural Medicine vs. Orthodox Medicine" Utah: Woodland Publishing.

Chan, M. (2008). Address at the WHO Congress on Traditional Medicine in Beijing, People's Republic of China on $7^{\text {th }}$ November, 2008.

Chetley, A. (2007). How to improve the use of medicines by consumers. Geneva: World Health Organization.

Echebiri, R.N. and Mbanasor, J.A. (2003). Rural Age Distribution and Farm Labour Supply in Food Crop Production Systems in Abia State, Nigeria. Journal of Tropical and Subtropical Agrosystems, 2 (3), pp 129-136.

Falodun, A. (2010). Herbal medicine in Africa-distribution, standardization and prospects. Research Journal of Phytochemistry, 4, pp154-161.

Food and Agriculture Organisation. (2008). Pathways to Success: Success Stories in Agricultural Production and Food Security.

Osemene, K.P., Elujoba, A.A. and Ilori, M.O. (2011). A Comparative Assessment of Herbal and Orthodox Medicine in Nigeria. Research Journal of Medical Sciences, 5 (5), pp 280-285.

Shehu, R.A. and Mallam, S.B. (2007). Practice and Efficacy of Alternative Medicine in Nigeria. A Journal of Health, Education and Sports Science, 6 (1), pp10 - 23.

Umunakwe, T. (2010). Orthodox medicine's disappointment, Alternative medicine to the rescue? Nigerian Tribune.

WHO (2012). World Malaria Report.

World Bank (2012). World development indicators.

World Health Organisation (2002). WHO Traditional Medicine Strategy, 2002 - 2005. Geneva: World Health Organization.

World Health Organisation (2008). Traditional Medicine (Key Facts). Fact sheet №134. 
Yussuph, A.K. (2008). "Utilization of Primary Health Care Facilities among Rural Dwellers in Ona-Ara Local Government Area of Oyo State." Unpublished B.Agric Thesis in the Department of Agricultural Extension and Rural Development, University of Ibadan, Nigeria, pp 41. 